\title{
Expression of BRCA1 gene in ewe mammary epithelial cells during pregnancy: regulation by growth hormone and steroid hormones
}

\author{
K Laud, L Hornez ${ }^{1}$, I Gourdou, L Belair, A Arnold, J P Peyrat ${ }^{1}$ and J Djiane \\ Laboratoire de Biologie Cellulaire et Moléculaire, Institut National de la Recherche Agronomique, 78352 Jouy-en-Josas Cedex, France and ${ }^{1}$ Laboratoire \\ d'Oncologie Moléculaire Humaine, Centre Oscar Lambret, 59020 Lille Cedex, France \\ (Correspondence should be addressed to J Djiane; Email: djiane@diamant.jouy.inra.fr)
}

\begin{abstract}
Objective: Steroid hormones (estradiol and progesterone) in association with prolactin and growth hormone are involved in lobulo alveolar development of the mammary gland during pregnancy. We hypothesized that the BRCA1 gene may be induced by these different hormones.

Methods and Results: In this study, we have demonstrated by Northern blot and in situ hybridization, that the expression of ovine (o) BRCA1 mRNA in mammary epithelial cells increased dramatically during a short period in the second half of pregnancy (days 70 to 112) and decreased at the end of pregnancy. The increase in oBRCA1 mRNA expression is concomitant with rapid lobulo alveolar growth. Using an in vivo protocol to artificially induce mammary gland development, we demonstrated by the real-time RT-PCR method that growth hormone in association with estrogen, progesterone and hydrocortisone induces an increase of BRCA1 mRNA expression in the ewe mammary gland. Moreover, we showed that estradiol and progesterone induce oBRCA1 expression in primary cultures of ewe mammary gland.

Conclusions: These results suggest that BRCA1 is a potential regulator of the effects of steroid hormones and growth hormone in the induction of mammary epithelial cell proliferation.
\end{abstract}

European Journal of Endocrinology 145 763-770

\section{Introduction}

Hormones of pituitary and ovarian origins, including estrogen, progesterone, prolactin (PRL) and growth hormone (GH), play an important role in the control of normal and breast tumor cell proliferation (1). However, during mammary gland growth, the specific genes induced by these hormones have not been completely identified. BRCA1 is the breast and ovarian cancer susceptibility gene (2). Women carrying germline mutations in the BRCA1 gene present a markedly elevated risk of breast and ovarian cancers. This observation strongly suggests that the BRCA1 gene may play a critical role in the regulation of mammary gland growth. To support this hypothesis, different studies indicate that the murine BRCA1 gene is involved in tissue proliferation and differentiation (37). BRCA1 acts on normal growth and development of embryonic cells; the nullizygous mouse models developed have shown abnormalities in cellular proliferation as well as early embryonic lethality (8-9). Moreover, BRCA1 is expressed in all tissues of the developing mouse, particularly those that are rapidly proliferating and undergoing differentiation $(3,4,6,7)$. More specifically, in the mouse mammary gland, the expression of BRCA1 message is up-regulated during puberty and pregnancy $(3,4,6,7)$. The positive correlation between BRCA1 expression and cellular proliferation may be explained by in vitro studies showing that this gene is regulated in a cell cycle-dependent fashion, with a progressive increase in BRCA1 mRNA levels during G1 reaching maximal levels at the G1/S transition (5, 11). It has been shown that BRCA1 activates transcription of the cell-cycle regulator cyclin-dependent kinase (CDK)-inhibitor p21 waf1/CiP1 (12). All these studies suggest that up-regulation of BRCA1 represents a feedback mechanism in rapidly proliferating cells. In vitro studies have demonstrated that estrogen stimulates BRCA1 mRNA expression in human breast cancer cell lines and is correlated with cell proliferation (1316). In ovariectomized mice, the level of BRCA1 transcript is increased by estrogen plus progesterone treatment $(4,6)$. However, no similar studies have been performed to analyze the effect of peptide hormones such as PRL and GH, known to be implicated in the growth of the mammary gland during pregnancy. 
Considering all these studies, we hypothesized that the BRCA1 gene could be potentially regulated by PRL and GH during mammary gland development. Therefore, by Northern blot analysis and in situ hybridization, we investigated the spatial and temporal pattern during pregnancy and lactation of BRCA1 mRNA expression in the ewe mammary gland. In order to examine the hormonal regulation of BRCA1 gene expression, mammary gland growth and differentiation were artificially induced by hormonal treatments associating steroids (estradiol, progesterone, hydrocortisone) and ovine GH (oGH) or ovine placental lactogen (oPL). The levels of BRCA1 mRNA were quantified by the real-time RT-PCR method in the different groups of ewe treated with these peptide hormones. Moreover, using real-time RT-PCR, we analyzed the effects of these hormones on BRCA1 mRNA levels in primary cultures of ewe mammary gland.

\section{Materials and methods}

\section{Animals}

Virgin ewes of the Préalpes du Sud breed were used in all experiments. Estrus was synchronized using intravaginal sponges containing $40 \mathrm{mg} 9 \alpha$-fluoro- $17 \alpha-$ acetoxy-9 $\alpha$-fluoro $11 \beta$-hydroxyprogesterone for 14 days (Intervet, Angers, France).

In order to determine the BRCA1 gene expression profile during mammary gland development, this tissue was collected from 2 or 3 primiparous ewes on days 15 , 70,112 and 141 of pregnancy and on day 3 of lactation.

For hormonal treatment experiments, ewes were divided into 5 experimental groups, each consisting of 3 virgin ewes. Group 1 received s.c. injections of $0.5 \mathrm{mg} /$ $\mathrm{kg}$ estradiol (Roussel-UCLAF, Romainville, France) and $1.25 \mathrm{mg} / \mathrm{kg}$ progesterone (Roussel-UCLAF) twice daily for the first 7 consecutive days and received $1 \mathrm{mg} / \mathrm{kg}$ hydrocortisone acetate (Roussel-UCLAF) i.m. twice daily from days 18 to 20 of the experiment. In groups 2 and 4, the ewes were treated as in group 1 and received, respectively, oGH $(0.18 \mathrm{mg} / \mathrm{kg})$ or oPL $(0.4 \mathrm{mg} / \mathrm{kg})$ i.m. twice daily from days 11 to 20 . To study the role of oPRL, groups 3 and 5 received the same treatment as groups 2 and 4 together with bromocryptine during the 20 days of the experiment. The recombinant hormones oGH and oPL were a generous gift from Prof. A Gertler (The Hebrew University of Jerusalem, Rehovot, Israel).

\section{Ex vivo culture of mammary acini}

Ewe mammary gland at day 106 of pregnancy was collected, cut into small pieces and washed in a solution of $1 \times$ EBSS (Earle's balanced salts; Gibco BRL-Life Technologies, Cergy Pontoise, France) containing 3\% sodium bicarbonate, $1 \%$ penicillin (Gibco BRL), 1\% streptomycin (Gibco BRL) and 0.1\% gentamicin (Gibco BRL). The pieces of mammary gland were digested at $37^{\circ} \mathrm{C}$ with $200 \mathrm{U}$ type III collagenase (Sigma, Saint Quentin Fallavier, France) and type III hyaluronidase (Sigma). A DNase I treatment (Boehringer Mannheim, Meylan, France) was performed for $30 \mathrm{~min}$ at $37^{\circ} \mathrm{C}$. Mammary acini were filtered and washed with $1 \times$ EBSS. After centrifugation, acini were grown in DMEM-HAM F12 medium containing $2 \%$ ultroser (Biosepra, Cergy Pontoise, France), 1\% glutamine (Gibco BRL), 1\% penicillin (Gibco BRL), 1\% streptomycin (Gibco BRL) and $0.1 \%$ gentamicin (Gibco BRL). This method allows us to obtain a $90 \%$ pure preparation of mammary epithelial cells. Cells were incubated with $100 \mathrm{pg} / \mathrm{ml}$ estradiol or $1 \mu \mathrm{g} / \mathrm{ml}$ progesterone for 24 and $48 \mathrm{~h}$.

\section{Cloning of ovine BRCA1 CDNA}

RT-PCR was used to amplify a specific fragment of the ovine BRCA1 cDNA. RT-PCR was performed as previously described (17) using $3 \mu \mathrm{g}$ total mRNA of ovine mammary gland, and human oligonucleotide primers chosen according to the human exon $11 \mathrm{cDNA}$ sequence (2). The sense primer 5'-CAACATAACAGATGGGCTGGAAG-3' (nucleotides 1067-1090) and the antisense primer $5^{\prime}$-TGTGAGGGGACGCTCTTG- ${ }^{\prime}$ (nucleotides 1597-1616) were used to amplify a $549 \mathrm{bp}$ fragment. The PCR fragment was subcloned into the pGEM-T cloning vector (Promega, Lyon, France) and sequenced by automated DNA sequencing (Applied Biosystems, Foster City, CA, USA). The nucleotide sequence of the ovine BRCA1 cDNA was $80 \%$ identical to that of the human BRCA1 cDNA. This specific fragment was used as a probe for Northern blot analysis and in situ hybridization.

\section{RNA extraction and Northern blot analysis}

Total RNAs were prepared by the guanidinium isothiocyanate/phenol method, as described by Chomczynski and Sacchi and modified by Puissant and Houdebine (18). Twenty micrograms total RNA were electrophoresed on a 1.5\% agarose/formaldehyde gel and transferred to a Zeta-probe membrane (BioRad, Ivrysur-Seine, France). Membranes were prehybridized and hybridized at $65^{\circ} \mathrm{C}$ in $0.5 \mathrm{~mol} / \mathrm{l}$ sodium dihydrogenophosphate $\mathrm{pH} 7.2,7 \%$ SDS, $1 \mathrm{mmol} / \mathrm{l}$ EDTA, $0.5 \%$ nonfat dry milk and $3 \times 10^{6}$ c.p.m. $/ \mathrm{ml}$ of a random hexamer ${ }^{32} \mathrm{P}$-dCTP-labelled oBRCA1 probe. Blots were washed in $4 \times \mathrm{SSC}, 0.5 \%$ SDS at $65^{\circ} \mathrm{C}$. Signals on the autoradiographs were scanned with a STORM-860 machine (Molecular Dynamics, Bondoufle, France).

\section{Real-time quantitative one-step RT-PCR}

The real-time quantitative PCR method is based on the use of the $5^{\prime}$ nuclease assay described by Holland et al. 
(19). This method measures PCR product accumulation at each cycle through a dual-labeled fluorogenic probe (TaqMan probe, Perkin Elmer). One fluorescent dye linked to the $5^{\prime}$ end of the probe oligonucleotide is used as a reporter (FAM (6-carboxyfluorescein)); its emission is quenched by a second fluorescent dye linked to the $3^{\prime}$ end (TAMRA (6-carboxy-tetramethylrhodamine)). During the extension phase of the PCR cycle, the fluorescent hybridization probe is cleaved by the $5^{\prime}$ nuclease activity of the Taq polymerase. The nuclease degradation of the probe releases the quenching of FAM fluorescent emission, resulting in an increase in peak fluorescence emission. The parameter $\mathrm{Ct}$ is defined as the cycle number at which the fluorescence generated by cleavage of the probe exceeds a threshold limit (10 times the standard deviation of the base line). Thus, the BRCA1 gene copy number in the mammary gland was quantified by measuring $\mathrm{Ct}$ and by using a standard curve to determine copy number in the sample.

RT-PCR amplification One-step RT-PCR was performed with 12.5 U M-MLV (Moloney murine leukemia virus reverse transcriptase; Promega), $1.25 \mathrm{U}$ Taq polymerase (Ampli Taq Gold, Perkin Elmer), $300 \mu \mathrm{mol} / \mathrm{l}$ dATP, dCTP, dGTP and $600 \mu \mathrm{mol} / \mathrm{l} \mathrm{dUTP}, 5 \mathrm{mmol} / \mathrm{l}$ $\mathrm{MgCl}_{2}, 1 \times$ TaqMan buffer, and 10 pmole of each primer and fluorogenic probe, in a final volume of $50 \mu \mathrm{l}$. One-step RT-PCR was carried out in the ABI Prism 7700 Sequence Detection System (Perkin-Elmer Applied Biosystems, Saint Quentin en Yvelines, France) which detects the signal from the fluorogenic probe during PCR. The thermal cycling conditions were: reverse transcription at $48{ }^{\circ} \mathrm{C}$ for $30 \mathrm{~min}$, activation of Taq polymerase at $95^{\circ} \mathrm{C}$ for $10 \mathrm{~min}$ and 40 cycles at $95{ }^{\circ} \mathrm{C}$ for $15 \mathrm{~s}$ and at $60{ }^{\circ} \mathrm{C}$ for $1.5 \mathrm{~min}$. Each assay included a standard curve and $100 \mathrm{ng}$ (to quantify oBRCA1) or $50 \mathrm{ng}$ (to quantify ovine glyceraldehyde-3phosphate dehydrogenase, oGAPDH) of ovine mammary gland total RNA, in duplicate.

Standard curve construction RNAs were synthesized with the Promega in vitro transcription system using Sp6 RNA polymerase promoters of a linearized pGEM-T vector containing a 544 bp fragment of the human exon 11 oBRCA1 cDNA corresponding to nucleotides 1067/1616. After a DNase I treatment, RNAs were quantified by optic density. The standard curve used for real-time quantitative RT-PCR was performed on dilution of $100 \mathrm{pg}$ to $0.001 \mathrm{pg}$ RNA pool.

Primers and fluorogenic probe The oligonucleotides and probe sequences were chosen according to the fragment of oBRCA1 cDNA characterized in this study. The primer sense (5'-GGAAGAAAAGAACTGTGTAAGCAG$\left.3^{\prime}\right)$, primer antisense (5'-TATTAACTTCTGACGACTCGTGC- $\left.3^{\prime}\right)$ and probe $\left(5^{\prime}\right.$-AACCTGCATGCTCTGACAGTCCTG$\left.3^{\prime}\right)$ used allowed the amplification of a cDNA fragment of
$153 \mathrm{bp}$. The level of BRCA1 transcript was standardized to oG3PDH transcript, quantified by real-time RT-PCR in the same conditions as those defined by BRCA1. The oG3PDH sense (5'-GGTCACCAGGGCTGCTTTTA-3') and antisense $\left(5^{\prime}\right.$-TGCCATGGGTGGAATCATACT- $\left.3^{\prime}\right)$ primers and the fluorogenic probe (5'-CTGGCAAAGTGGACATCGTTGCCATC-3') amplified a cDNA fragment of $113 \mathrm{bp}$.

\section{In situ hybridization}

An in situ hybridization (ISH) procedure was performed as described previously (20) using antisense and sense RNA probes specific for the oBRCA1 nucleotide sequence. The riboprobes were transcribed using $\mathrm{T} 7$ or Sp6 RNA polymerase (Gibco BRL-Life Technologies) and labeled with $\left[\alpha_{-}{ }^{35}\right.$ S]UTP $(1000 \mathrm{Ci} / \mathrm{mmol}$, Amersham Pharmacia Biotech, Orsay, France). Labeled sense probe was used as a negative control for ISH. Sections were hybridized with $2 \times 10^{6}$ c.p.m./ml antisense or sense probe overnight at $55^{\circ} \mathrm{C}$. Slides were dehydrated through graded concentrations of ethanol and air dried prior to dipping in photo-emulsion (NTB2, Kodak). Slides were developed for 15 days and analyzed by bright- and dark-field microscopy using a Leica microscope.

\section{Results}

\section{Cloning of the ovine BRCA1 cDNA probe}

A specific fragment of the oBRCA1 cDNA was isolated by RT-PCR using ewe mammary gland at 106 days of pregnancy and oligonucleotide primers located in exon 11 of the human BRCA1 gene. The size of the amplified fragment was $544 \mathrm{bp}$ The nucleotide sequence of oBRCA1 revealed $80 \%$ and $71 \%$ identity to the published sequences of human and mouse BRCA1 cDNA respectively $(2,21)$. This oBRCA1-exon 11 probe was used for our hybridization experiments.

\section{Expression of the ovine BRCA1 transcript during pregnancy and lactation}

The spatial and temporal pattern of oBRCA1 mRNA expression during pregnancy and lactation was examined by Northern blot and in situ hybridization in the ewe mammary gland. As shown in Fig. 1, a single transcript of approximately $7.5 \mathrm{~kb}$ was observed in the ovine mammary gland at all stages of pregnancy studied. The oBRCA1 mRNA expression level was low at the beginning of pregnancy, increased at day 112 of pregnancy and decreased at the end of pregnancy (day 141). No oBRCA1 transcript was detected during lactation. The $18 \mathrm{~S}$ rRNA was used as a standard for Northern blot analysis (Fig. 1).

To identify the mammary gland cell types expressing oBRCA1 mRNA, in situ hybridization analysis was carried out on mammary gland tissue sections obtained 


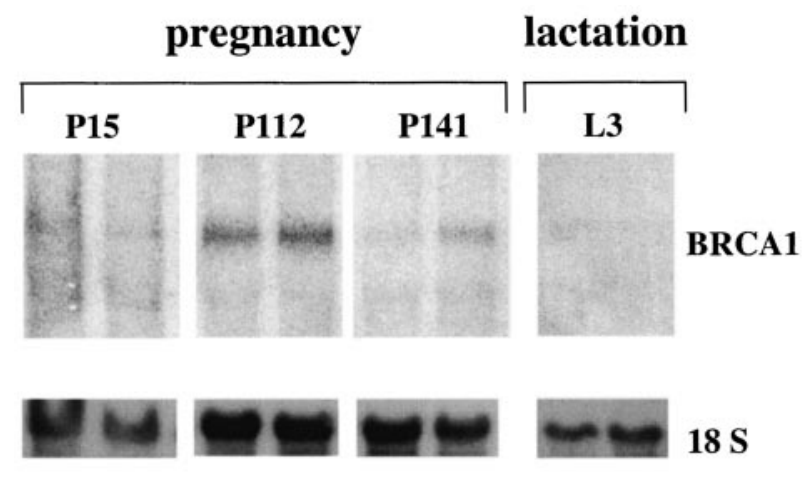

Figure 1 Northern blot analysis of oBRCA1 mRNA expression in ovine mammary gland during pregnancy $(P)$ and lactation $(L)$. Twenty micrograms total RNA were electrophoresed, transferred to a blotting membrane, and hybridized with a radiolabeled oBRCA1exon 11 probe (upper panel). The membrane was stripped and reprobed with a mouse $\alpha^{-32}$-labeled 18S cDNA probe (lower panel).

on days 15,70 , and 112 of pregnancy and on day 3 of lactation using the ${ }^{35}$ S-labeled antisense oBRCA1-exon 11 probe. Control tissue sections treated with the ${ }^{35}$ S-labeled sense probe (Fig. 2, I, J) exhibited no specific signal, further demonstrating the specificity of the reaction. The oBRCA1 transcript expression was predominantly detected in the mammary epithelial cells (Fig. 2, A-F). In addition, BRCA1 mRNA was slightly expressed in the mammary stroma, particularly in the stromal portion adjacent to the epithelial cells (Fig. 2, E, F). Moreover, this experiment confirmed the pattern of oBRCA1 expression observed by Northern blot analysis during the second half of pregnancy (Fig. 2). Indeed, oBRCA1 expression was detectable in the middle of pregnancy (day 70; Fig. 2, C, D). At day 112 of pregnancy, the oBRCA1 mRNA expression was increased dramatically in the alveolar epithelial cells (Fig. 2, E, F). No signal was observed in the mammary gland at day 15 of pregnancy (Fig. 2, A, B) and at day 3 of lactation (Fig. 2, G, H).

\section{Hormonal regulation of BRCA1 expression}

The observation that BRCA1 mRNA levels were upregulated during pregnancy suggested that the expression of this gene may be modulated directly or indirectly by ovarian hormones and peptides hormones such as GH or PRL known to act during mammary gland development. Also, during pregnancy the plasma levels of oPL are very high. Recently, we have demonstrated that this placental hormone has a mammogenic effect (22) in the ewe. In order to study the in vivo effects of these different hormones on oBRCA1 expression, ewes were treated with these hormones following the experimental procedure previously described (see Materials and methods). The procedure allows the artificial induction of mammary gland growth and differentiation. For each animal, the oBRCA1 mRNA expression level was determined by real-time one-step RT-PCR and normalized to the ovine GAPDH expression (oGAPDH) level (Fig. 3). Specificity of the amplified PCR products was confirmed by Southern blot analysis using the oBRCA1-exon 11 probe (data not shown). Subsequent sequencing of the 154 bp fragment revealed $100 \%$ identity to the BRCA1 nucleotide sequence described in this study (data not shown). By comparison with the group treated with estradiol, progesterone and hydrocortisone (group 1), the level of oBRCA1 mRNA was strongly increased by oGH treatment (group 2). In contrast, treatment with oPL had no detectable effect on the level of oBRCA1 mRNA expression (group 4). To analyze the role of PRL secretion on the oBRCA1 gene expression, the ewes of groups 2 and 4 received an additional treatment with bromocryptine (groups 3 and 5). This treatment inhibits pituitary PRL secretion. The oBRCA1 mRNA levels in ewes treated with oGH (group 2) and oPL (group 4) were not significantly different from those observed in the groups of ewes treated with bromocryptine (groups 3 and 5).

Previous studies indicated that BRCA1 mRNA expression is stimulated by estrogen or progesterone treatment in human mammary gland cell lines (13$16)$ and in ovariectomized animals $(4,6)$. These results prompted us to examine the effects of ovarian steroid hormones on BRCA1 mRNA expression in primary culture of ovine mammary gland. Again, BRCA1 expression was quantified by real-time RT-PCR and normalized to oGAPDH expression (Fig. 4) After 24 and $48 \mathrm{~h}$ of culture, oBRCA1 mRNA levels were high in response to estrogen alone and increased slightly in response to progesterone alone. By comparison, the induction of oBRCA1 mRNA expression after estrogen and progesterone treatment was neither synergistic nor completely antagonistic. Moreover, the up-regulation of BRCA1 mRNA expression in mammary gland cells treated with estrogen or/and progesterone reached maximal levels after $24 \mathrm{~h}$ of cell culture.

\section{Discussion}

Previous investigations have studied the temporal pattern of BRCA1 mRNA expression in the mouse mammary gland during pregnancy and lactation. However, no similar studies have been reported in an animal model having a longer pregnancy duration; such studies would allow a more precise analysis of the pattern of BRCA1 gene expression during mammary gland development. Northern blot analysis revealed that in ewe mammary gland an approximately $7.5 \mathrm{~kb}$ transcript was detected at all stages of pregnancy examined, consistent with previous results obtained in human and mouse mammary glands $(2,21)$. As demonstrated by Northern blot and by in situ hybridization analysis, we found that the level of BRCA1 

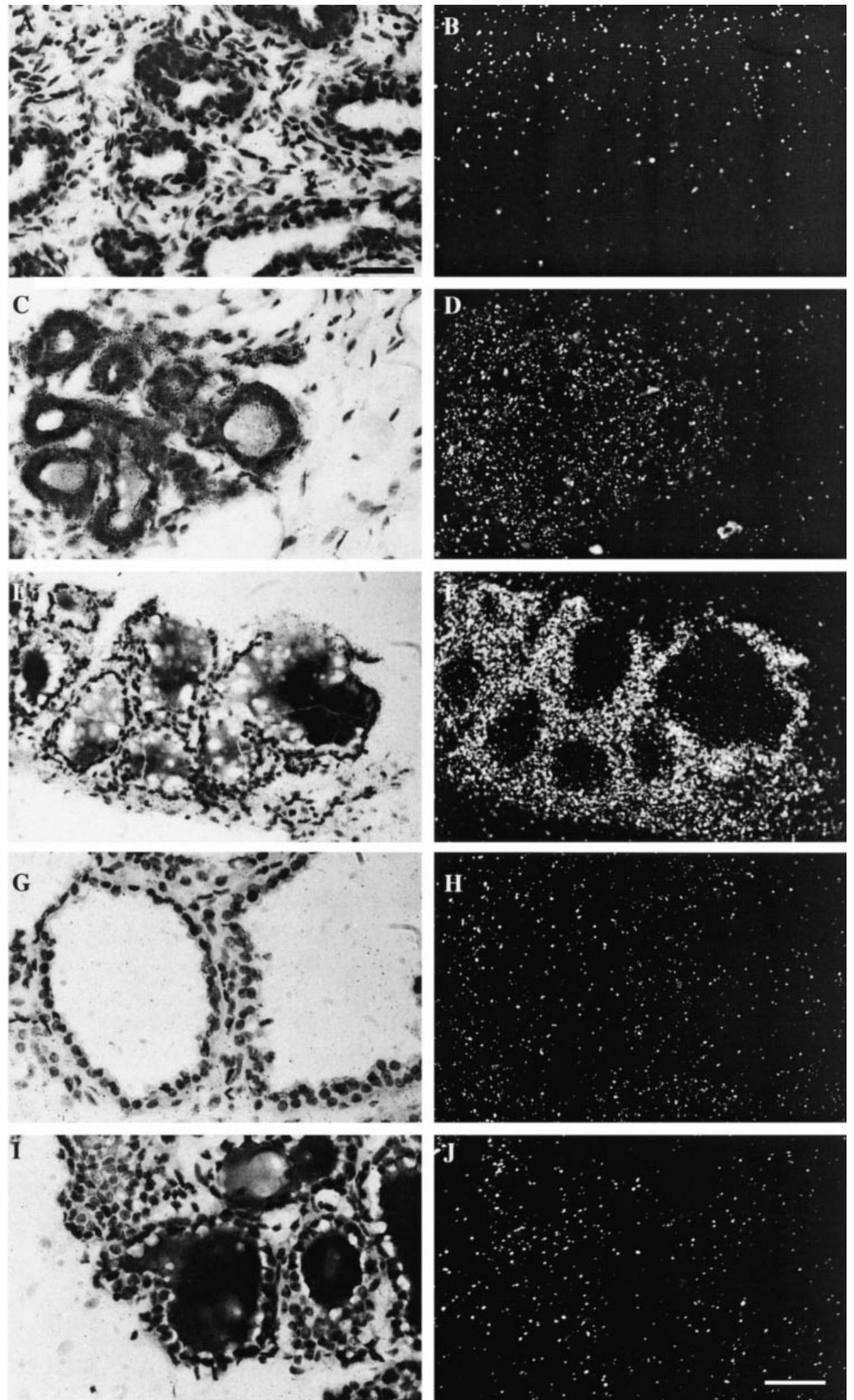

Figure 2 Cellular localization and expression of oBRCA1 mRNA in ovine mammary gland by in situ analysis. Bright-field (left) and dark-field (right) photomicrographs of in situ hybridization analysis performed on frozen sections of ovine mammary gland on day $15(A, B)$, day $70(C$, $D$ ), and day $112(E, F)$ of pregnancy and day 3 of lactation $(G, H)$ using an ${ }^{35}$ S-labeled antisense oBRCA1-exon 11 probe. A tissue section of ovine mammary gland on day 112 of pregnancy $(\mathrm{I}, \mathrm{J})$ was hybridized with the sense probe and used as a control of specificity. Bar=39 $\mu \mathrm{m}$. 


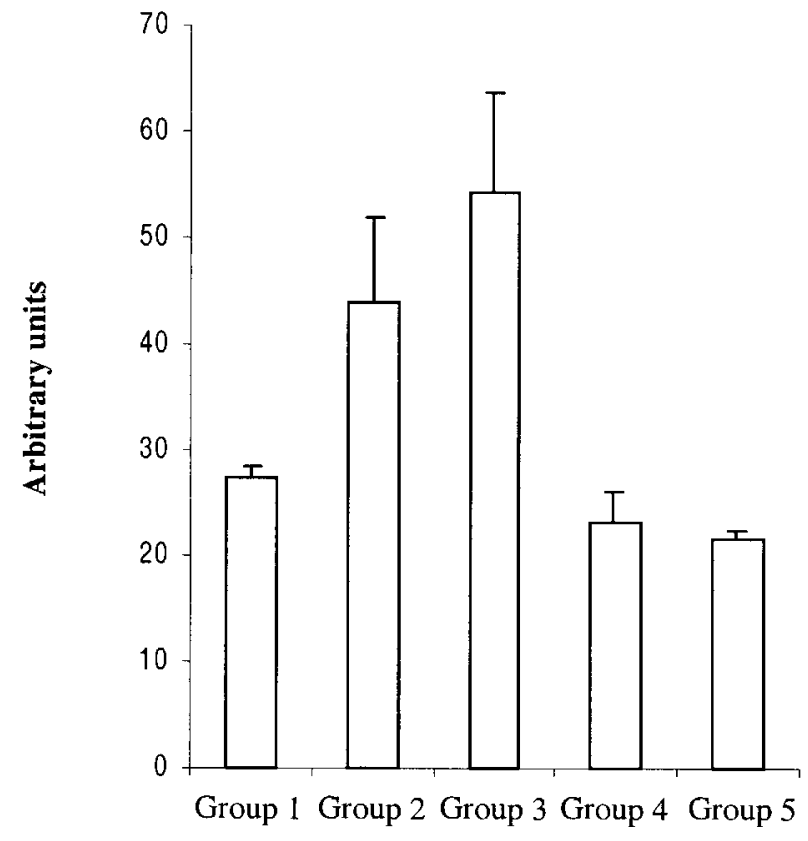

Figure 3 Hormonal regulation analysis of oBRCA1 mRNA levels by real-time RT-PCR. Total mRNA (100 $\mathrm{ng}$ or $50 \mathrm{ng}$ ) was used to quantify the expression of the oBRCA1 gene (100 ng mRNA) and oGAPDH (50 ng mRNA) transcripts. The results are the means \pm S.E.M. $(n=3)$. Group 1: estradiol, progesterone and hydrocortisone acetate. Group 2: estradiol, progesterone, hydrocortisone acetate and oGH. Group 3: estradiol, progesterone, hydrocortisone acetate, oGH and bromocryptine. Group 4: estradiol, progesterone, hydrocortisone acetate, oPL. Group 5: estradiol, progesterone, hydrocortisone acetate, OPL and bromocryptine.

mRNA was dramatically increased during a short period in the second half of pregnancy (days 70 to 112 ) with a maximal expression level around day 112. Interestingly, this pattern of oBRCA1 gene expression is

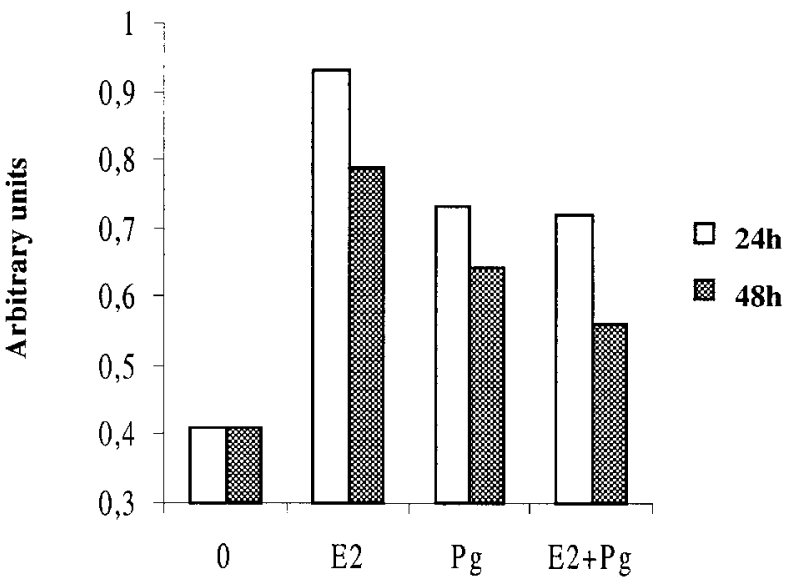

Figure 4 Effect of estrogen (E2; $100 \mathrm{pg} / \mathrm{ml}$ ) or/and progesterone $(\mathrm{Pg} ; 1 \mu \mathrm{g} / \mathrm{ml})$ treatment on oBRCA1 expression in primary culture of ovine mammary gland. Quantitative analysis was performed by real-time RT-PCR and normalized by the amount of GAPDH mRNA after $24 \mathrm{~h}$ (open) or $48 \mathrm{~h}$ (shaded) of culture. correlated with the intensity of the growth of the alveolar tissue. Indeed, the maximal expression level of the oBRCA1 gene is correlated with an important increase of DNA synthesis observed in ewe mammary gland (23). This result suggests that BRCA1 gene expression is up-regulated during active cell proliferation and may be involved in its control. In vitro studies have previously demonstrated that BRCA1 mRNA expression is induced in rapidly proliferating cells and down-regulated in quiescent cells (5). During the cell cycle, BRCA1 mRNA and protein levels increase progressively during the $\mathrm{G} 1$ phase to reach maximal levels at the G1/S transition (before DNA synthesis) $(11,24)$. Moreover, BRCA1 activates transcription of the cyclin-dependent kinase inhibitor $\mathrm{p} 21^{\text {waf1/CiP1 }}$, inducing cell cycle arrest $(12,25,26)$, suggesting that BRCA1 negatively regulates proliferation in mammary epithelial cells. In addition, it has previously been demonstrated, in breast cells, that the antisensemediated reduction in BRCA1 expression induces an increase in cellular proliferation $(27,28)$ and that overexpression of BRCA1 inhibits cellular growth (29). All these studies argue for the existence of a regulatory loop in which cell proliferation induces BRCA1 expression which, by a feedback mechanism, negatively regulates proliferation of these cells.

Recent reports have demonstrated that BRCA1 interacts with Rad 51, a homolog of Escherichia coli RecA, known to be involved in double-strand breakrepair $(30,31)$. Thus, the induction of BRCA1 expression in actively growing cells may activate DNA damage repair pathways to prevent genomic damage during rapid cell proliferation. This observation raises the possibility that the induction of BRCA1 expression may be a protective response to possible DNA damage during active cell proliferation in the mammary gland.

In the mammary gland, the observation that BRCA1 mRNA levels are increased in developing alveoli suggests that oBRCA1 gene expression may be regulated by mammogenic hormones (ovarian and pituitary hormones and placental lactogen). Using an in vivo experimental protocol reproducing the induction of mammary gland development, we have demonstrated that $\mathrm{GH}$ treatment induces an increase of BRCA1 mRNA levels in the ewe mammary gland (group 2). Although GH plasma levels are unchanged during pregnancy, different studies have shown that this hormone stimulates mammary gland growth. It has been clearly demonstrated that the administration of oGH to virgin ewes, in combination with estrogen/ progesterone and hydrocortisone treatment, induces DNA synthesis in mammary gland (22). In addition, the stimulation of oGH release by human growth hormone releasing factor strongly induces mammogenesis in virgin ewes $(32,33)$ and an increase in plasma levels of insulin-like growth factor-I (IGF-I). In the mammary gland, the mitogenic effect of $\mathrm{GH}$ is probably mediated indirectly via IGF-I production. We 
analyzed IGF-I levels in the different groups of animals and we found that $\mathrm{GH}$ treatment induces a marked increase in IGF-I plasma levels (data not shown). These data strongly suggest that the induction of BRCA1 gene expression by GH treatment may be mediated by IGF-I. In agreement with this hypothesis, in vitro studies have shown that IGF-I stimulates BRCA1 mRNA expression in the MCF-7 tumoral breast cell line (15).

It cannot be excluded that the up-regulation of BRCA1 expression by GH, as described in this study, was partially due to a direct stimulatory effect on the transcription of the BRCA1 gene in the mammary epithelial cells. However, several studies have shown that BRCA1 gene transcription induced by estrogen or growth factors (such as IGF-I) is in fact a consequence of the mitogenic activity of these hormones in the mammary gland growth and is not a direct effect (13, 15, 16).

Previous studies performed in vitro and in vivo have demonstrated that estrogen and progesterone stimulate BRCA1 gene expression $(4,6,13-15)$. In primary cultures of ewe mammary gland, BRCA1 gene expression was increased by estrogen or progesterone. We cannot exclude the possibility that the basal level of BRCA1 expression may be increased by the presence of phenol red in the culture medium, due to its estrogenic activity. These results support the idea that the increase of BRCA1 mRNA levels is one of the general consequences of cell proliferation induced by estrogen and/or progesterone.

Surprisingly, oPL treatment had no effect on the expression of oBRCA1. Although this hormone has a mammogenic effect, it does not stimulate IGF-I production (22). oPL is also involved in the differentiation of mammary epithelial cells, a period when oBRCA1 mRNA levels decrease dramatically.

In conclusion, BRCA1 gene expression is up-regulated in the ewe mammary gland during the first half of pregnancy and is associated with intensive cellular proliferation in response to mammogenic hormones. The stimulation of BRCA1 gene expression may represent a crucial event to avoid DNA damage during intense cell proliferation and, in this way, it may be necessary for harmonious lobulo alveolar development of the mammary gland during pregnancy.

\section{References}

1 Houdebine LM, Djiane J, Dusanter-Fourt I, Martel P, Kelly PA, Devinoy E et al. Hormonal action controlling mammary activity. Journal of Dairy Science 198568 489-500.

2 Miki Y, Swensen J, Shattuck-Eidens D, Futreal PA, Harshman K, Tavtigian S et al. A strong candidate for the breast and ovarian cancer susceptibility gene BRCA1. Science 1994266 66-71.

3 Lane TF, Deng C, Elson A, Lyu MS, Kozak CA \& Leder P. Expression of BRCA1 is associated with terminal differentiation of ectodermally and mesodermally derived tissues in mice [published erratum appears in Genes and Development 199610 365]. Genes and Development $199592712-2722$.
4 Marquis ST, Rajan JV, Wynshaw-Boris A, Xu J, Yin GY, Abel KJ et al. The developmental pattern of BRCA1 expression implies a role in differentiation of the breast and other tissues. Nature Genetics 199511 17-26.

5 Rajan JV, Wang M, Marquis ST \& Chodosh LA. BRCA2 is coordinately regulated with BRCA1 during proliferation and differentiation in mammary epithelial cells. PNAS 199693 13078-13083.

6 Rajan JV, Marquis ST, Gardner HP \& Chodosh LA. Developmental expression of BRCA2 colocalizes with BRCA1 and is associated with proliferation and differentiation in multiple tissues. Developmental Biology $1997 \mathbf{1 8 4} 385-401$.

7 Blackshear PE, Goldsworthy SM, Foley JF, McAllister KA, Bennett LM, Collins NK et al. BRCA1 and BRCA2 expression patterns in mitotic and meiotic cells of mice. Oncogene 199816 61-68.

8 Gowen LC, Johnson BL, Latour AM, Sulik KK \& Koller BH. Brca1 deficiency results in early embryonic lethality characterized by neuroepithelial abnormalities. Nature Genetics 199612 191-194.

9 Hakem R, de la Pompa JL, Sirard C, Mo R, Woo M, Hakem A et al. The tumor suppressor gene BRCA1 is required for embryonic cellular proliferation in the mouse. Cell $1996 \mathbf{8 5} 1009-1023$.

10 Liu CY, Flesken-Nikitin A, Li S, Zeng Y \& Lee WH. Inactivation of the mouse BRCA1 gene leads to failure in the morphogenesis of the egg cylinder in early postimplantation development. Genes and Development $1996 \mathbf{1 0} 1835-1843$.

11 Gudas JM, Li T, Nguyen H, Jensen D, Rauscher F Jr \& Cowan KH. Cell cycle regulation of BRCA1 messenger RNA in human breast epithelial cells. Cell Growth and Differentiation 19967 717-723.

12 Somasundaram K, Zhang H, Zeng YX, Houvras Y, Peng Y, Zhang $\mathrm{H}$ et al. Arrest of the cell cycle by the tumour-suppressor BRCA1 requires the CDK-inhibitor p21WAF1/CiP1. Nature 1997 389 187-190.

13 Gudas JM, Nguyen H, Li T \& Cowan KH. Hormone-dependent regulation of BRCA1 in human breast cancer cells. Cancer Research $1995 \mathbf{5 5} 4561-4565$.

14 Spillman MA \& Bowcock AM. BRCA1 and BRCA2 mRNA levels are coordinately elevated in human breast cancer cells in response to estrogen. Oncogene 199613 1639-1645.

15 Marks JR, Huper G, Vaughn JP, Davis PL, Norris J, McDonnell DP et al. BRCA1 expression is not directly responsive to estrogen. Oncogene 199714 115-121.

16 Romagnolo D, Annab LA, Thompson TE, Risinger JI, Terry LA, Barrett JC et al. Estrogen upregulation of BRCA1 expression with no effect on localization. Molecular Carcinogenesis $199822102-$ 109.

17 Laud K, Gourdou I, Belair L, Keisler DH \& Djiane J. Detection and regulation of leptin receptor mRNA in ovine mammary epithelial cells during pregnancy and lactation. FEBS Letters 1999463 194-198.

18 Puissant C \& Houdebine LM. An improvement of the single-step method of RNA isolation by acid guanidinium thiocyanatephenol-chloroform extraction. Biotechniques 19908 148-149.

19 Holland PM, Abramson RD, Watson R \& Gelfand DH. Detection of specific polymerase chain reaction product by utilizing the $5^{\prime}$ to $3^{\prime}$ exonuclease activity of Thermus aquaticus DNA polymerase. PNAS 199188 7276-7280.

20 Cassy S, Charlier M, Belair L, Guillomot M, Charron G, Bloch B et al. Developmental expression and localization of the prolactin receptor (PRL-R) gene in ewe mammary gland during pregnancy and lactation: estimation of the ratio of the two forms of PRL-R messenger ribonucleic acid. Biology of Reproduction $1998 \mathbf{5 8}$ $1290-1296$.

21 Bennett LM, Haugen-Strano A, Cochran C, Brownlee HA, Fiedorek FT Jr \& Wiseman RW. Isolation of the mouse homologue of BRCA1 and genetic mapping to mouse chromosome 11 . Genomics 199529 576-581.

22 Kann G, Delobelle-Deroide A, Belair L, Gertler A \& Djiane J. Demonstration of in vivo mammogenic and lactogenic effects of recombinant ovine placental lactogen and mammogenic effect 
of recombinant ovine $\mathrm{GH}$ in ewes during artificial induction of lactation. Journal of Endocrinology 1999160 365-377.

23 Denamur R. Les acides nucléiques et les nucléotides libres de la glande mammaire au cours de la lactogénèse et de la galactopoï̀se. Proceedings of the 2nd International Congress on Endocrinology, London. Excerpta Medica International Congress Series $196583434-462$.

24 Vaughn JP, Davis PL, Jarboe MD, Huper G, Evans AC, Wiseman RW et al. BRCA1 expression is induced before DNA synthesis in both normal and tumor-derived breast cells. Cell Growth and Differentiation 1996 7 711-715.

25 Ouchi T, Monteiro AN, August A, Aaronson SA \& Hanafusa H. BRCA1 regulates p53-dependent gene expression. PNAS 1998 $952302-2306$.

26 Zhang H, Somasundaram K, Peng Y, Tian H, Zhang H, Bi D et al. BRCA1 physically associates with p53 and stimulates its transcriptional activity. Oncogene 199816 1713-1721.

27 Thompson ME, Jensen RA, Obermiller PS, Page DL \& Holt JT. Decreased expression of BRCA1 accelerates growth and is often present during sporadic breast cancer progression. Nature Genetics 19959 444-450.

28 Rao VN, Shao Ahmad M \& Reddy ES. Antisense RNA to the putative tumor suppressor gene BRCA1 transforms mouse fibroblasts. Oncogene 199612 523-528.
29 Holt JT, Thompson ME, Szabo C, Robinson-Benion C, Arteaga CL, King MC et al. Growth retardation and tumour inhibition by BRCA1 [see comments] [published erratum appears in Nature Genetics 199819 102]. Nature Genetics 199612 298-302 .

30 Shinohara A, Ogawa H, Matsuda Y, Ushio N, Ikeo K \& Ogawa T. Cloning of human, mouse and fission yeast recombination genes homologous to RAD51 and recA [published erratum appears in Nature Genetics 19935 312]. Nature Genetics 19934 239-243.

31 Scully R, Chen J, Plug A, Xiao Y, Weaver D, Feunteun J et al. Association of BRCA1 with Rad51 in mitotic and meiotic cells. Cell 199788 265-275.

32 Kann G, Perier A \& Martinet J. Use of human growth hormone releasing factor (hGRF1-29) $\mathrm{NH}_{2}$ as a mammotropic hormone in the ewe. Journal of Animal Science 198866 (Suppl 1) 389 (Abstract).

33 Kann G. Evidence for a mammogenic role of growth hormone in ewes: effects of growth hormone-releasing factor during artificial induction of lactation. Journal of Animal Science 199775 25412549 .

Received 7 May 2001

Accepted 8 August 2001 